\title{
Design and Comparative Analysis of Compact Bioinspired Leaf-shaped Antenna Using Different Substrate Material for UWB and X-band Applications
}

\author{
Ushaben Keshwala1,2, Sanyog Rawat ${ }^{3, *}$, Kanad Ray ${ }^{2}$ \\ ${ }^{1}$ Amity University Noida, Uttar Pradesh, India \\ ${ }^{2}$ Amity University Rajasthan, Jaipur, India \\ ${ }^{3}$ Manipal University Jaipur, India
}

(Received 10 January 2021; revised manuscript received 24 March 2021; published online 09 April 2021)

\begin{abstract}
The paper presents the design and analysis of a compact semicircular antenna for UWB applications. The paper highlights and presents the comparative study for a leaf-shaped antenna using various substrate materials. The comparative analysis has been carried out for VSWR, gain, and $S_{11}$ characteristics of the antenna. The compact leaf-shaped antenna presented in this paper is designed using Rogers RT Duroid 5880 of a size $12 \times 19 \mathrm{~mm}^{2}$. The designed antenna achieves a very wide bandwidth of $4.6-15.01 \mathrm{GHz}$ (fractional bandwidth of $106.2 \%$ ) and a maximum gain of $3.454 \mathrm{dBi}$ at $12.646 \mathrm{GHz}$. This antenna can be used for UWB and X-band applications.
\end{abstract}

Keywords: Leaf shaped antenna, Bioinspired antenna, Substrate material, UWB antenna.

DOI: $10.21272 /$ jnep.13(2).02018

PACS numbers: 33.70.Jg, 28.52.Fa

\section{INTRODUCTION}

Microstrip antenna is one of the most popular and widely used antennas for wireless communication. Microstrip antenna offers various advantages due to its different attractive features like thin profile, compact size, lightweight, easy fabrication, and compatibility for integrated circuits. Since the allocation of UWB (ultrawide band) by FCC [1], different kinds of antennas have been proposed by many researchers for wireless and UWB applications [2-5]. In literature, various different shapes of patch antennas are designed and proposed like elliptical, circular, square, rectangular, pentagon, triangular, etc. [2-5].

In addition to conventional monopole antennas, the study and design of microstrip antennas with patch designs on leaves or the leaf-shaped patch has triggered the interest of researchers [6]. Design and analysis of various different bioinspired antennas and nature inspired leaf-shaped antennas had been proposed by many researchers [7-15]. A leaf-shaped bowtie slot antenna for ultra-wideband applications was proposed with an impedance bandwidth of $7.0-10.0 \mathrm{GHz}$ range [7]. The $30 \times 60 \mathrm{~mm}^{2}$ antenna is a self-complementary structure of leaf shape and achieved a maximum gain of $7.5 \mathrm{dBi}$. An antenna of size $80 \times 80 \mathrm{~mm}^{2}$ with leafshaped patch geometry was proposed with a very wide impedance bandwidth of $1.3-29.7 \mathrm{GHz}$ [8]. The antenna exhibits an omnidirectional radiation pattern and a very wide bandwidth covering $\mathrm{L}, \mathrm{C}, \mathrm{X}$, and $\mathrm{Ku}$ bands. In [9] a comparative study on the parameters of the leaf-shaped antenna was presented. The comparative study was carried for compact coaxial fed leaf-shaped antenna using a hybrid artificial intelligence network.

A printed leaf-shaped monopole antenna designed on Rogers RT/Duroid 5880 with partial ground plane was presented [10]. The reflection coefficient $<-10 \mathrm{~dB}$ is obtained in the range $3.02 \mathrm{GHz}-13.28 \mathrm{GHz}$ by compact size $40 \times 40 \mathrm{~mm}^{2}$ antenna. A novel compact size $\left(25 \times 2 \mathrm{~mm}^{2}\right)$ leaf-shaped antenna was proposed with an impedance bandwidth of $3.0-9.5 \mathrm{GHz}$. The leafshaped patch is designed by three ellipses and CPW feed, the impedance bandwidth is improved by one fourth arc shaped slit in the ground plane.

In the above-presented antennas, the different substrates with different thicknesses and dielectric constants were used for the antenna design. In the presented paper the bio-inspired leaf antenna is presented for UWB and X-band applications. The comparative study and analysis are carried out for different substrate materials to compare the antenna performance.

\section{ANTENNA STRUCTURE AND DESIGN PROCESS}

The proposed leaf-shaped antenna configuration is shown in Fig. 1. The antenna is designed on Rogers 5880 substrate with a dielectric constant $\left(\varepsilon_{r}\right)$ of 2.2 and size $12 \times 19 \mathrm{~mm}^{2}$. The antenna is fed by a microstrip line of width $2.8 \mathrm{~mm}$. The conducting radiating patch and ground are designed on opposite sides of the substrate. The bioinspired leaf-shaped patch is designed by considering half-sinusoidal tapering as shown in Fig. 1c. The partial ground with a rectangular slot in the upper edge is considered for improving the impedance bandwidth. The optimized dimensional parameters of an antenna are presented in Table 1.

Table 1 - Summary of the optimized parameters of an antenna structure

\begin{tabular}{|c|c|c|c|}
\hline Parameter & $\begin{array}{c}\text { Dimensions } \\
(\mathrm{mm})\end{array}$ & Parameter & $\begin{array}{c}\text { Dimensions } \\
(\mathrm{mm})\end{array}$ \\
\hline$W$ & 12 & $L_{p}$ & 10.67 \\
\hline$L$ & 19 & $L_{1}$ & 1.5 \\
\hline$L_{g}$ & 6.5 & $W_{f}$ & 2.8 \\
\hline$W_{p}$ & 7.68 & $W_{1}$ & 2 \\
\hline$W_{p 1}$ & 3.84 & \multicolumn{2}{|l}{} \\
\hline
\end{tabular}

\footnotetext{
* sanyog.rawat@jaipur.mnipal.edu

The results were presented at the International Conference on Multifunctional Nanomaterials (ICMN2020)
} 

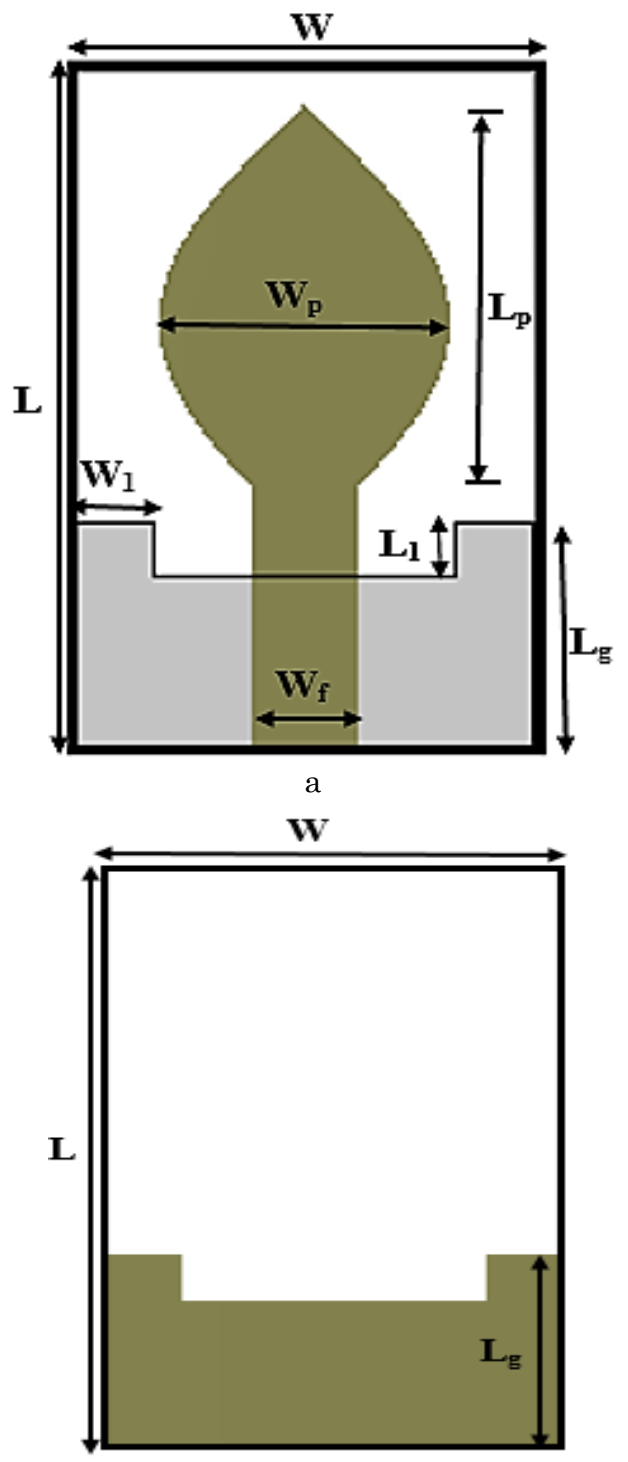

b

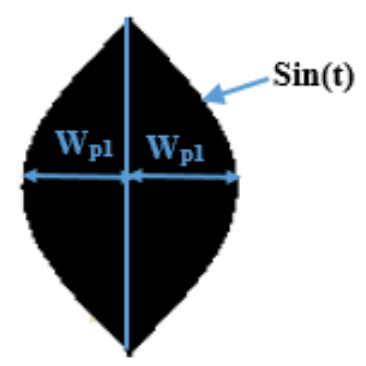

c

Fig. 1 - Proposed antenna structure: (a) front view; (b) back view; (c) leaf patch

\section{COMPARATIVE STUDY OF SUBSTRATE MATERIALS}

The performance of the antenna is dependent on various parameters like substrate material, the thickness of the substrate, and dielectric constant. To study the effect, an exhaustive parametric analysis is carried out and the obtained results are compared and presented.
The substrate materials considered in these designs are FR-4, Rogers 5880, and polyimide. The characteristic parameters for the considered substrates are presented in Table 2. The obtained refection coefficient $\left(S_{11}\right)$ characteristics for the considered substrates are shown in Fig. 2a. The refection coefficient specifies the amount of power reflected by the antenna as given below:

$$
\text { Refection Coefficient }\left(S_{11}\right)=10 \log \left(\frac{P_{r}}{P_{i}}\right),
$$

where $P_{r}$ is the reflected power, and $P_{i}$ is the incident or input power to the antenna. From the presented curves it can be observed that the presented prototype works as a wideband antenna with FR-4 and Rogers 5880 substrate. On the other hand, polyimide substrate has a narrowband antenna with resonant frequency at $4.63 \mathrm{GHz}$. With FR-4 as a substrate, the antenna has acquired an impedance bandwidth of $4.10-12.03 \mathrm{GHz}$ and with Rogers 5880 substrate, the impedance bandwidth obtained is $4.68-15.01 \mathrm{GHz}$. The voltage standing wave ratio (VSWR) tells how properly an antenna is matched with the feed line. The VSWR characteristic is presented in Fig. 2b; comparison of the antenna gain is displayed in Fig. 2c.

The total efficiency and radiations efficiency of an antenna comparison are graphically shown in Fig. 3a and Fig. 3b, respectively.

Table 2 - The characteristics parameters for the considered substrates

\begin{tabular}{|l|c|c|c|}
\hline \multicolumn{1}{|c|}{ Substrate } & $f_{l}(\mathrm{GHz})$ & $f_{h}(\mathrm{GHz})$ & $S_{11}$ \\
\hline FR-4 & 4.19 & 12.03 & -38.25 at $4.80 \mathrm{GHz}$ \\
\hline Rogers 5880 & 4.63 & 15.01 & -26.92 at $13.17 \mathrm{GHz}$ \\
\hline Polyimide & 4.15 & 5.2 & -19.1 at $4.61 \mathrm{GHz}$ \\
\hline $\begin{array}{l}\text { Maximum } \\
\text { gain }\end{array}$ & \multicolumn{3}{|c|}{ Maximum efficiency } \\
\cline { 2 - 4 } $\begin{array}{l}2.76 \text { at } \\
10.77 \mathrm{GHz}\end{array}$ & $95.7 \%$ at $10.77 \mathrm{GHz}$ & $96.6 \%$ at $10.77 \mathrm{GHz}$ \\
\hline $\begin{array}{l}3.45 \text { at } \\
12.64 \mathrm{GHz}\end{array}$ & $95.9 \%$ at $13.00 \mathrm{GHz}$ & $96.2 \%$ at $12.88 \mathrm{GHz}$ \\
\hline $\begin{array}{l}1.32 \mathrm{at} \\
5.1 \mathrm{GHz}\end{array}$ & $86 \%$ at $4.8 \mathrm{GHz}$ & $90.5 \%$ at $5.1 \mathrm{GHz}$ \\
\hline
\end{tabular}

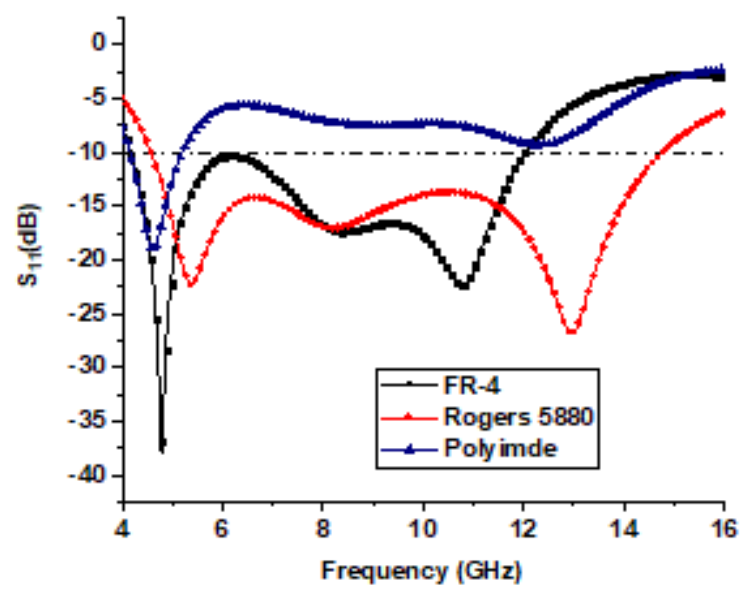

a 


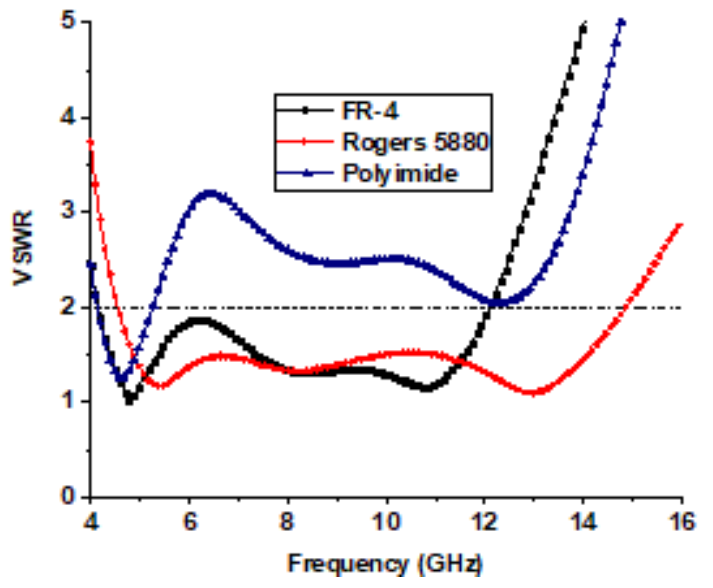

$\mathrm{b}$

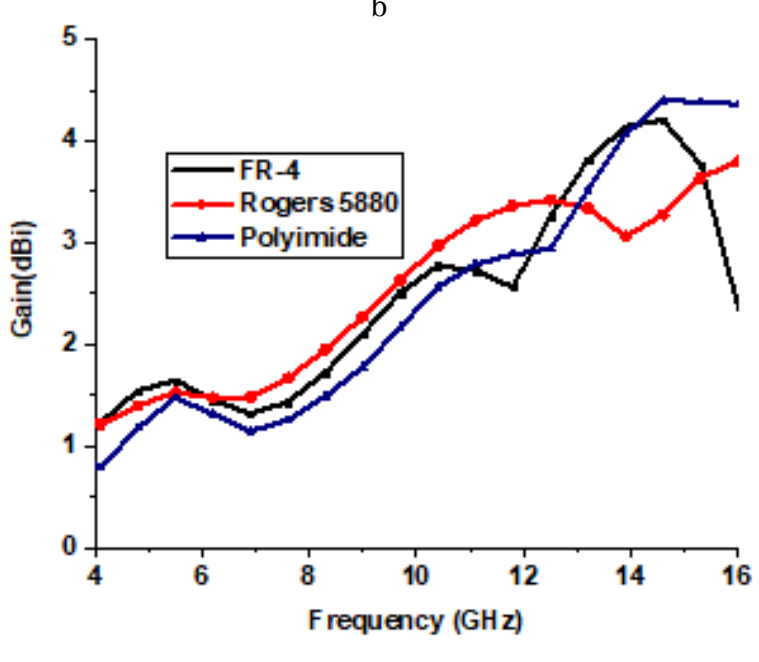

$\mathrm{c}$

Fig. 2 - (a) $S_{11}$ variations with frequency; (b) VSWR variations with frequency; (c) gain variations for different substrates

After comparing the antenna performance characteristics in terms of impedance bandwidth, maximum gain, VSWR, and efficiency the Rogers 5880 is the most suitable substrate for the proposed antenna design. Thus by considering the Rogers 5880 as a fundamental substrate the surface current distributions and radiation patterns at resonating frequencies are plotted.

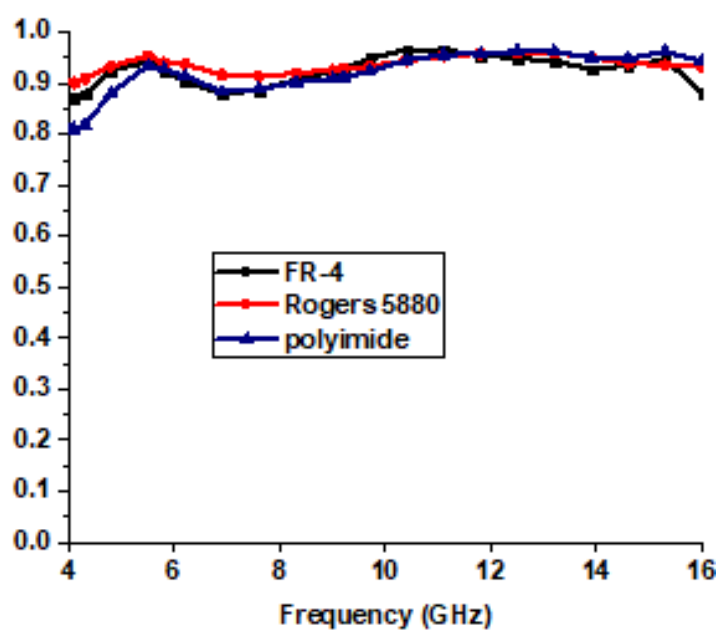

a

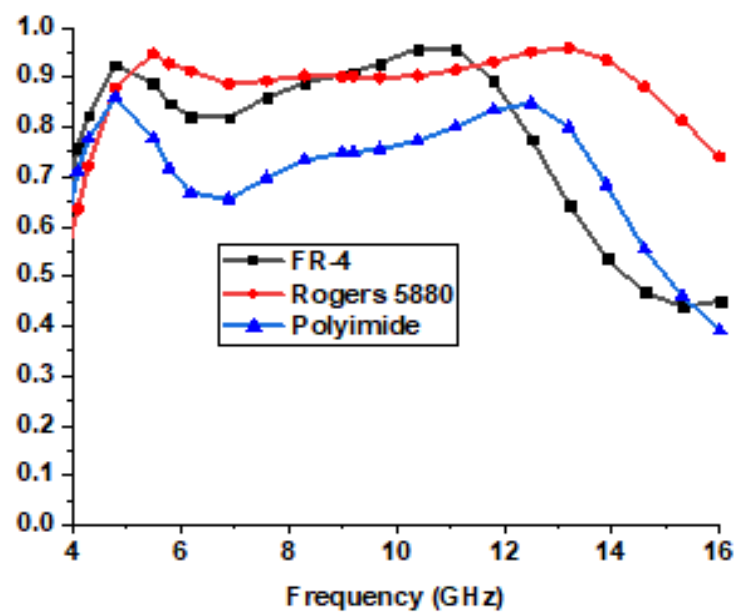

$\mathrm{b}$

Fig. 3- (a) Total efficiency; (b) radiation efficiency for different substrates

\section{RESULTS AND DISCUSSION}

The final antenna prototype consist of leaf-shaped patch and partial ground with a rectangular slot. As it can be observed from the $S_{11}$ characteristics, the antenna with Rogers 5880 resonates at $5.46 \mathrm{GHz}$ with $S_{11}$ value of $-22.03 \mathrm{~dB}$, at $8.1 \mathrm{GHz}$ with $S_{11}$ of $-17.38 \mathrm{~dB}$, and at $13.16 \mathrm{GHz}$ with $-26.97 \mathrm{~dB}$. The surface current distributions of the antenna at resonant frequencies is shown in Fig. 4. At $5.46 \mathrm{GHz}$ frequency, the current is mainly flowing through the lower part of the patch. Similarly, the current is mainly concentrated in the lower patch at $13.16 \mathrm{GHz}$. On the other hand, at $8.1 \mathrm{GHz}$ the current is distributed thoughout patch and the ground.

Fig. 5 shows the $E$-field $\left(\Phi=0^{\circ}\right)$ and $H$-field $\left(\Phi=90^{\circ}\right)$ radiation patterns at $5.46 \mathrm{GHz}, 8.1 \mathrm{GHz}$, 13.16 GHz. The $E$-field at 5.46, 8.1 GHz, and $13.16 \mathrm{GHz}$ is nearly omnidirectional. The bidirectional $H$-field radiation pattern is obtained with the main lobe pointing at $205^{\circ}$. At $8.1 \mathrm{GHz}$ main lobe with $3 \mathrm{~dB}$ angular width $0 f 161.5^{\circ}$ is obtained for H-field. At $13.16 \mathrm{GHz} H$-field with two minor lobes is obtained.

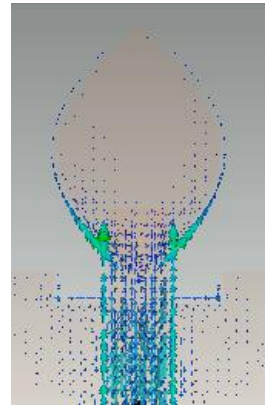

a

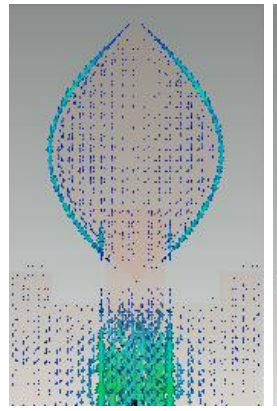

$\mathrm{b}$

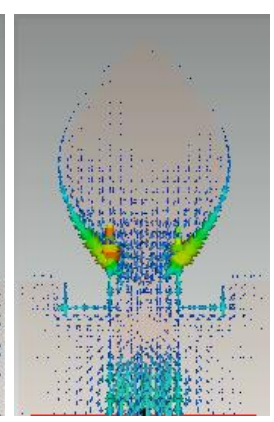

$\mathrm{c}$
Fig. 4 - Surface current distribution at resonating frequencies: (a) $5.46 \mathrm{GHz}$; (b) $8.1 \mathrm{GHz}$; (c) $13.16 \mathrm{GHz}$ 


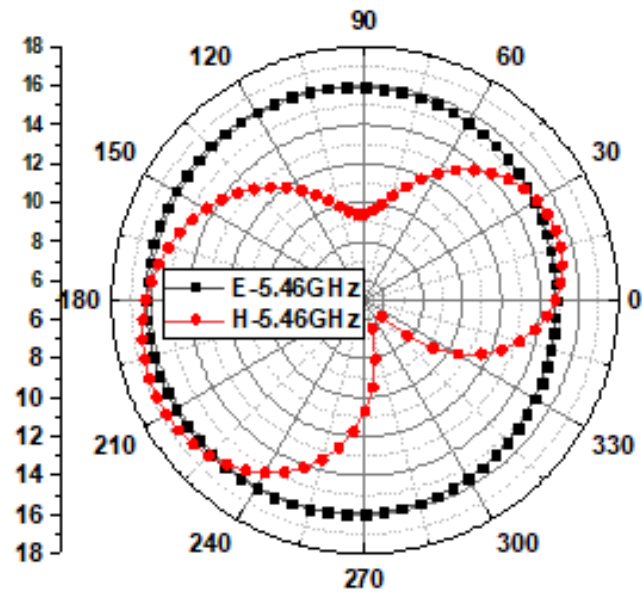

a

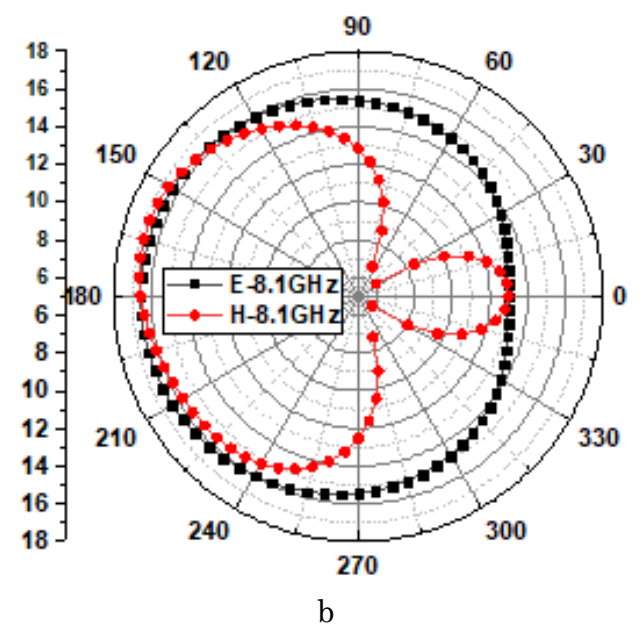

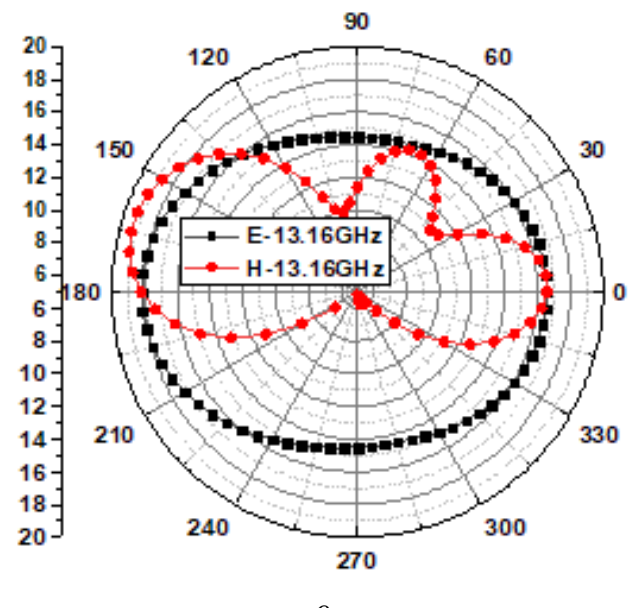

Fig. $5-E$-field and $H$-field radiation pattern at resonating frequencies: (a) $5.46 \mathrm{GHz}$; (b) $8.1 \mathrm{GHz}$; (c) $13.16 \mathrm{GHz}$

\section{CONCLUSIONS}

The main aim of this paper is to design, simulate, and analyze compact bioinspired leaf-shaped antenna for UWB and X-band application. To select the substrate material for antenna design comparative analysis is carried out for various performance characteristic parameters such as reflection coefficient $\left(S_{11}\right)$, VSWR (voltage standing wave ratio), gain, radiation efficiency, and total efficiency. FR-4, Rogers RT Duroid 5880, and polyimide substrates are selected for comparative study. The Rogers 5880 shows comparatively better performance and selected for the antenna design. The compact leaf antenna archives a very wide bandwidth of $4.63-15.01 \mathrm{GHz}$ and a maximum gain of $3.45 \mathrm{dBi}$ at $12.64 \mathrm{GHz}$. The compact size, wide bandwidth, omnidirectional radiation pattern and maximum efficiency make the antenna suitable for UWB and X-band applications.

9. U. Ozkaya, L. Seyfi, Neural Comput. Applic. 29, 35 (2018).

10. R. Seetharaman, E.G. Raj, P. Geethanjali, S. Hariram, M. Kannan, International Journal of Computer Applications 43, 6 (2012)

11. P. Singh, K. Ray, S. Rawat, Advances in Nature and Biologically Inspired Computing 419, 369 (2015).

12. P. Singh, R. Doti, J.E. Lugo, J. Faubert, S. Rawat, S. Ghosh, K. Ray, A. Bandyopadhyay, Advances in Intelligent Systems and Computing (AISC) 584, 213 (2016).

13. U. Keshwala, S. Rawat, K. Ray, Int. J. RF Microw. Comput.Aided Eng. 30, e22240 (2020).

14. P. Singh, K. Ray, S. Rawat, International Journal of Computer Information System and Industrial Management Applications (IJCISM) 8, 364 (2016).

15. P. Singh, R. Doti, J.E. Lugo, J. Faubert, S. Rawat, S. Ghosh, K. Ray, A. Bandyopadhyay, Advances in Intelligent Systems and Computing (AISC) 84, 201 (2017). 
Проектування та порівняльний аналіз компактної біотехнологічної листоподібної антени з використанням різних матеріалів підкладки для застосувань UWB та X-діапазонів

\author{
Ushaben Keshwala ${ }^{1,2}$, Sanyog Rawat ${ }^{3}$, Kanad Ray $^{2}$ \\ ${ }^{1}$ Amity University Noida, Uttar Pradesh, India \\ 2 Amity University Rajasthan, Jaipur, India \\ 3 Manipal University Jaipur, India
}

\begin{abstract}
У статті представлено проектування та аналіз компактної напівкруглої антени для застосувань UWB діапазону. У статті висвітлено та представлено порівняльне дослідження листоподібної антени з використанням різних матеріалів підкладки. Проведено порівняльний аналіз таких параметрів антени як VSWR, коефіціентів підсилення та $S_{11}$. Компактна листоподібна антена, яка представлена в ро-

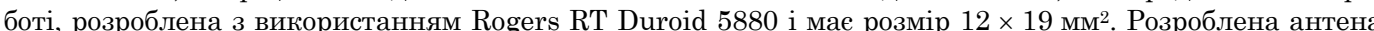
забезпечуе дуже широку пропускну здатність 4,6-15,01 ГГц (відносна пропускна здатність 106,2 \%) максимальний коефріцієнт підсилення 3,445 дБі при 12,646 ГГц. Ця антена може бути використана для UWB та X-діапазонів.
\end{abstract}

Ключові слова: Листоподібна антена, Біотехнологічна антена, Матеріал підкладки, Антена UWB. 